\title{
Zörög Zoltán
}

Eszterházy Károly Egyetem, Alkalmazott Informatika Tanszék

zorog.zoltan@uni-eszterhazy.hu

\section{ERP OKTATÁSI MODELL E-LEARNING TANANYAGOKKAL}

Az online oktatás folyamatosan növekvő felhasználása azt jelenti, hogy a diákok számára a hagyományos, személyes szemléletü eszközöket a virtuális osztályteremben ki kell terjeszteni. Kifejlesztett ERP e-Learning modellek összegyüjthetök a szakirodalomban, bár a nyílt irodalomban csak kevés ERP e-learning modell létezik.

A vállalatok az ERP-re támaszkodva kezelik, rendezik és elemzik az adatokat. Megfigyelik a megrendeléseket, számolják a költséglapjait és gondoskodnak a CRM-röl. Az ERPalkalmazások folyamatosan összekapcsolják az alkalmazottakat, és biztosítják, hogy minden részleg hozzáférhessen az általuk szükséges információkhoz. Az alkalmazottaknak azonban hatékony ERP online képzésre van szükségük ahhoz, hogy felhasználhassák ezt a szoftvert, és adatokat gyüjtsenek.

\section{Bevezetés}

Az ERP rendszerek használatának alapjait a hatvanas években helyezték le. Ebben az időben elsősorban a készletkezelés volt elötérben. A vállalatok döntése alapján kezdték le a számítógépes rendszerek használatát. Az információs technológiák fejlődésnek hatására a készletkezelés, a gyártási anyagszükséglet tervezés (MRP), illetve a termelési erőforrástervezés (MRP II) átkerült a számítógépekre. Az 1990-es években a vállalatok elkezdték használni a vállalati erőforrás-tervező rendszereket, így az MRP és MRP II rendszerek kombinációjaként létrejövő ERP rendszerek egyre inkább elterjedtek.

Napjaink gyors gazdasági döntéseinek meghozatalához egyre több vállalat használ ERP rendszert, amelyek a hatékonyságukkal, az üzleti folyamatok gyorsításával bizonyították fontosságukat.

Az ERP rendszerek müködtetéséhez elengedhetetlen az, hogy az alkalmazottak egyre magasabb szintü képzését elötérbe helyezzük és az ilyen típusú rendszerek használatának oktatását integráljuk a tantervekbe.

Másik oka az integrációnak, hogy az ERP rendszerek forgalmazó cégek folyamatosan fejlesztik eszközeiket a vállalatok üzleti folyamatainak, igényeiknek megfelelően. Ennek okán a szakemberek folyamatos képzése is szükségessé válik. Az egyetemi tantervekbe különböző modellek kerültek integrálásra az elmúlt években.

Az Eszterházy Károly Egyetem Gyöngyösi Károly Róbert Campusán lassan húsz évvel ezelőtt kezdődött el az a program, amelynek keretében a gazdaságtudományi és informatikai képzésben részt vevő hallgatók az integrált vállalatirányítási rendszerek (ERP) kezelésében szereznek jártasságot. Elmondhatjuk, hogy egyre jelentősebb azoknak a vállalatoknak a száma, ahol ilyen rendszert használnak a belső folyamatok összehangolására, a vállalat müködését visszatükröző adatok elektronikus tárolására, a vezetői döntések támogatására. Az 1. ábra az EU környező országaiban mutatja a rendszerek elterjedtségét vállalati méretkategóriánként. 


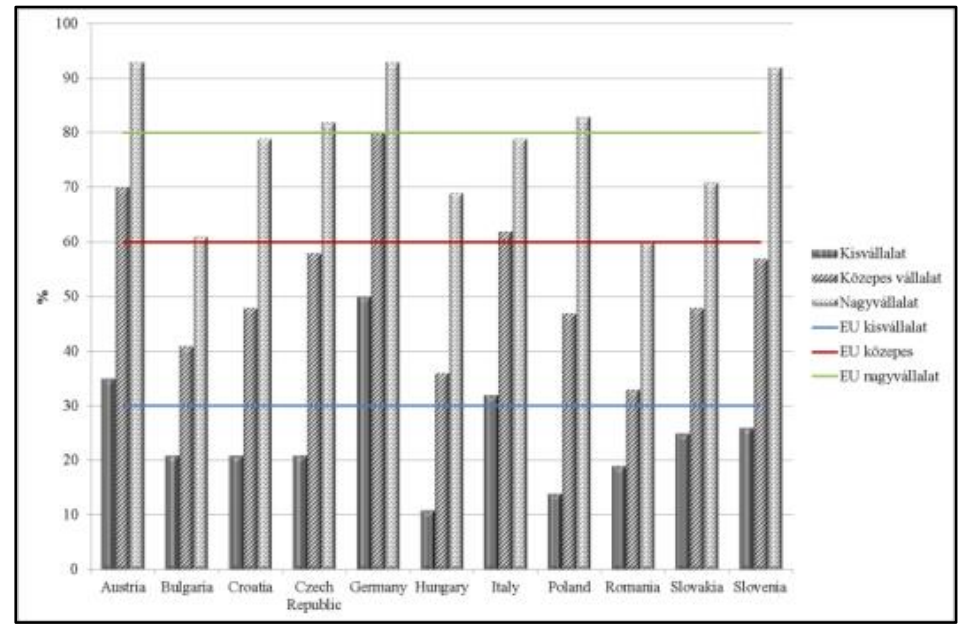

1. ábra. ERP-t használó vállalatok aránya az Európai Unió környezö országaiban vállalati méretkategóriánként 2015-ben

Forrás: EUROSTAT adatok alapján saját szerkesztés

Jól látható, hogy a kis- és közepes vállalati méretkategóriában Magyarországnak meglehetősen nagy a lemaradása nem csak az EU-s átlagtól, hanem a környező országok adataitól is. A nagyvállalati méretkategóriában is csupán Bulgáriát és Romániát elözzük meg.

\section{ERP rendszerek jelentősége}

Az ERP csupán egy eszköz arra, hogy a vállalkozás müködése biztosított legyen. A bevezetés nem old meg szervezeti problémákat, ennek célja egy egységes informatikai rendszer kialakítása. Segítségével megszünik a többszörös adattárolás, automatizálásra kerül az adatok továbbítása. A központi rendszerhez alrendszerek kapcsolódhatnak. A szinergia hatás eredményeként a teljes rendszer hatékonyabban müködik, mint a részegységek külön-külön. „Egy olyan rendszerröl van tehát szó, amely külső és belső forrásokból képes adatokat konvertálni információkká, képes kommunikálni, azaz: közvetíteni funkcionális döntési pontokat, ahol idöhöz kötött, hatásos, felelős döntéseket kell hozniuk - tervezési, irányítási és ellenörzési célra." (Lucey, 1989).

A tisztább kép kialakításához nagyban hozzájárul a megfelelően kialakított belső ellenőrzési rendszer, amely a modern vállalatirányítás egyik eszköze arra vonatkozóan, hogy a vállalati müködésböl eredö kockázat csökkenjen (Zörög et al. 2010). A vállalatmenedzsment szempontjából fontos, hogy összhang alakuljon ki a stratégiai és operatív célok között (Hágen - Kondorosiné, 2009).

A felmerülő költségek meghatározása mellett a beruházás hatása jelenik meg a döntést befolyásoló tényezőként, amely jelentős mértékben összefügg a megtérüléssel. A tipikus megtérülési pontokat mutatja be a 2 . ábra.

Az ábra tanúsága szerint a beruházáshoz közvetlen és közvetett előnyök egyaránt kapcsolódnak. A közvetlen előnyök közül a csökkenő szakértői igénnyel csak egyes területek esetében értek egyet. Például a partnerekkel, ügyfelekkel, vevőkkel folytatott személyes kommunikáción alapuló tevékenységek esetében ez nem feltétlenül valósul meg. A jól paraméterezett pénzügyi modul használatával viszont valóban kevesebb kontírozó könyvelöre van szükség. 


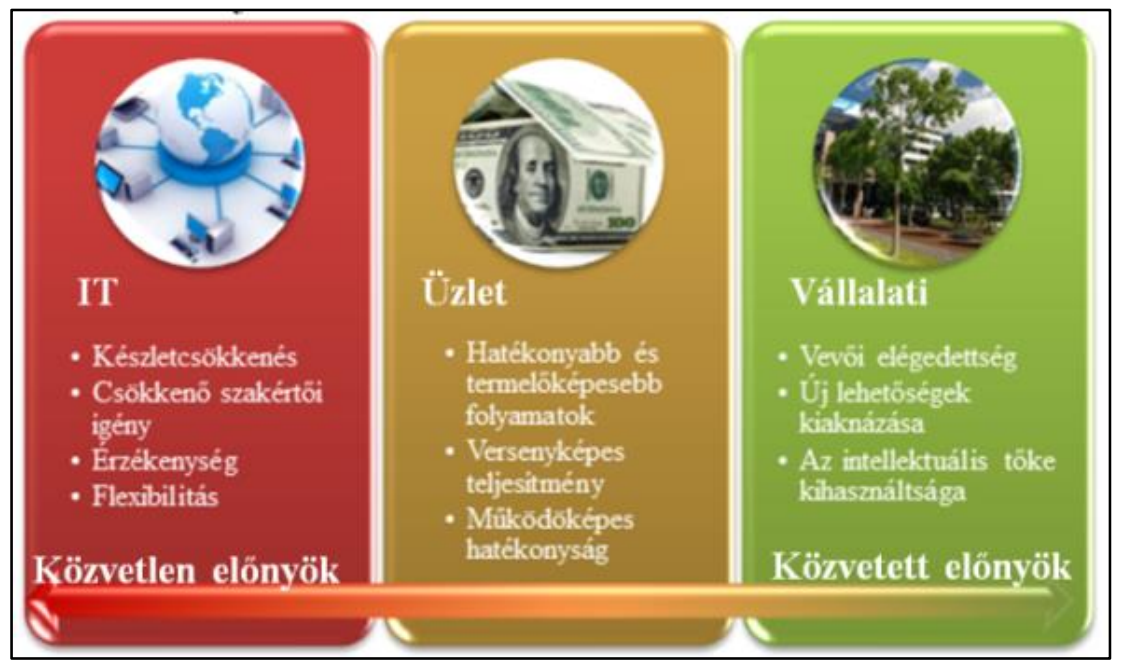

2. ábra. Az integráció megtérülési pontjai

Forrás: Webmethods, 2005 alapján saját szerkesztés

Az üzleti „szekcióban” feltüntetett lehetőségek közül a hatékonyabb és termelőképesebb folyamatok esetében vannak fenntartásaim, ugyanis ezek nem feltétlenül csak a beruházásnak köszönhetőek, mivel egy ERP bevezetését megelőzi az üzleti folyamatok átgondolása. Ez a bevezetés nélkül is megvalósulhat, és bizonyos szintü hatékonyság növekedés ebben az esetben is tapasztalható. Jóllehet az integrált rendszer automatizmusainak használatával a hatékonyság kiteljesedhet.

A vállalati szekcióban már erősen szubjektív hatások jelennek meg. Egyre többször találkozunk azonban a vállalkozások részéről a vevői elégedettséget mérő kérdőívekkel, amelyek alkalmasak lehetnek az ERP rendszer bevezetéséből származó elégedettség növekedésének kimutatására.

\section{Az ERP rendszer oktatási modellje}

A felsőoktatási intézmények gazdaságtudományi képzési terület hallgatóinak gyakorlatorientált képzésében fontos szerepet kell betölteni az információ menedzsmentnek. Az oktatási modell segítségével egy modern, számos vállalat által használt ERP rendszer müködését ismerhetik meg. Napjaink nagyon fontos erőforrásával - az információval tanulnak meg gazdálkodni, megismerik a gazdasági folyamatokat, azok fázisait. Az összeállított adatbázis, oktatási anyag elősegíti a rendszer- és folyamatszemléletü gondolkodásmód kialakulását.

A modell felépítését a 3. ábra mutatja be. 


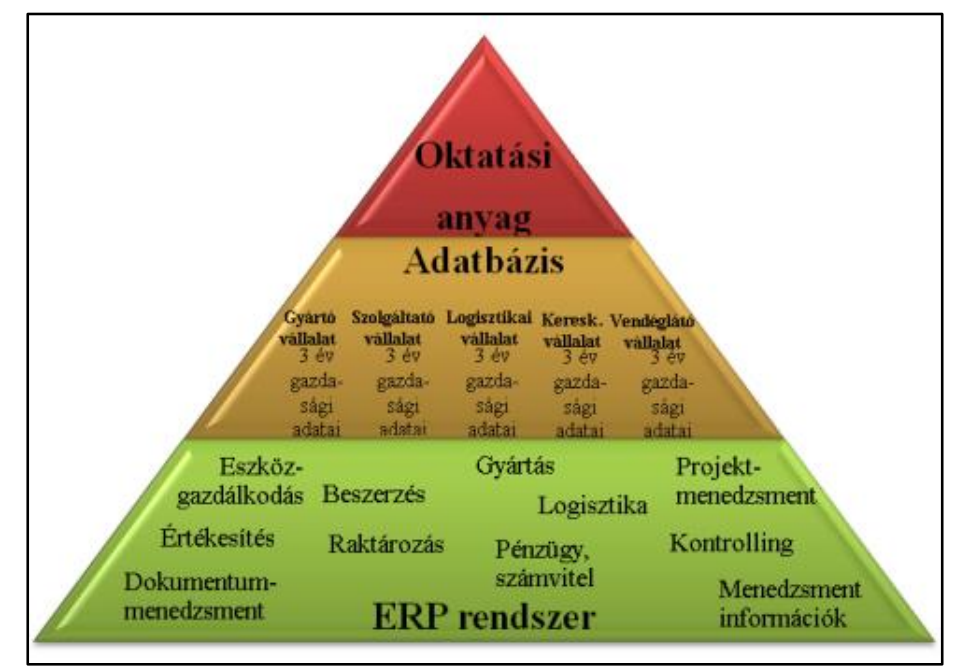

3. ábra. Az oktatási modell felépitése Forrás: saját szerkesztés

A modell alapját egy ERP rendszer képezi, amely a következő területek gazdasági folyamatait lefedő modulpalettát tartalmazza:

Értékesítés. Lehetővé teszi az üzleti (vevői) kapcsolatok és értékesített termékek áttekintését, támogatja a gyors számlalekérdezést, valamint a következő tevékenységeket foglalja magába:

Beszerzés. Az ajánlatkérések összehasonlításával támogatja a beszerzési döntések meghozatalát. Magába foglalja:

Eszközgazdálkodás. Rögzíti a vállalat tárgyi eszközeinek információit (beszerzéshez, értékcsökkenéshez kapcsolódó adatokat), kezeli különböző értékcsökkenési leírási módokat. Integráció a könyvelési modullal.

Projektmenedzsment. Elősegíti a hosszú távú, meghatározott célú, nagy komplexitású projektek tervezését. Lehetővé teszi a projekt ideje alatt a terv-tény összehasonlítást, monitorozást.

Gyártás. Segíti megszervezni a vállalkozás termékeinek legyártását. Támogatja a sorozatgyártást, kissorozatgyártást, a vevői igényeket kielégítő gyártást. Magába foglalja:

Logisztika. Lehetővé teszi a megrendelés folyamatának nyomon követését (e-logisztika), informálja a megrendelőt az aktuális megrendeléseikről, hozzáférhetővé teszi a régi megrendelések adatait.

Dokumentummenedzsment. Hagyományos és elektronikus iratok érkeztetésének, iktatásának, archiválásának, visszakeresésének támogatása, integráció az ERP modulokkal.

Integrált pénzügy, számvitel az alábbiakban felsorolt feladatok elvégzésére nyújtanak lehetőséget:

Controlling (tervezés, elemzés). Segítséget nyújt a pénzügyi év gazdasági folyamatainak megtervezésében, lehetővé teszi az ellenőrzést. Fontosabb gazdasági mutatókon keresztül segít nyomon követni a vállalat müködését. Múltbeli adatok felhasználásával elősegíti a következő pénzügyi év mérleg és eredményszámlák forgalmának tervezését.

Menedzsment információk, döntéselőkészítés. Real-time információk a vállalat pénzügyi, vagyoni, jövedelmezőségi, likviditási helyzetéről.

Raktározás. Elősegíti a raktárkészlet áttekinthetőségét, a raktárkészlet változása kapcsolódik a beszerzés illetve értékesítés modul tranzakcióihoz. Lehetőséget nyújt:

Az oktatási modell következő szintjét az ERP rendszer adatbázisa adja, amely öt különböző tevékenységi körű vállalkozás törzs-, illetve tranzakciós adatait tartalmazza:

A tevékenységi körök meghatározásánál igyekeztem figyelembe venni, hogy melyek azok a területek, ahol elterjedt a vállalatirányítási rendszerek használata, illetve, amely területeken 
tevékenykedő vállalatoknál helyezkednek el „előszeretettel” a gazdaságtudományok képzési területről kikerülő hallgatók.

Az adatbázisok a vállalatok három éves gazdasági adatait tartalmazzák, lehetővé téve ezzel az elemzések, tervek elkészítését, vezetői információk kimutatások, listák, jelentések formájában történő megjelenítését, elemzését Ezekre a vállalatonként kialakított adatbázisokra épül az oktatási anyag, amely a következő elemeket tartalmazza:

- a gazdasági szituációt leíró esettanulmány,

- használati útmutató, oktatási segédanyag,

- e-learning segédanyag.

Az esettanulmányok vállalati ágazatonként tartalmazzák az adott területen tevékenykedö vállalat gazdasági folyamataihoz kapcsolódó, jellemző, gyakran előforduló szituációkat leíró helyzetleírást.

Az esettanulmány tartalmazza:

- a szituáció pontos leírását,

- a feladat megoldásához szükséges segédanyagok elérési helyét,

- a szituációhoz kapcsolódó ellenőrző kérdéseket.

Az esettanulmányokban meghatározásra kerül, hogy a feladatok melyik vállalat adatbázisának segítségével oldhatóak meg.

Az esettanulmányok nem csupán az adatok rögzítésére helyezik a hangsúlyt, sokkal inkább a rögzített adatokból történő információk előállítására, döntés előkészítésére, probléma megoldására. Az esettanulmányok végén több, megoldásra váró feladat található, amelyek három különbözö nehézségi fokozatba sorolhatóak. Segítségükkel az ERP használata - akár egy esettanulmányon belül is - több különböző tantárgy gyakorlati oktatásába is integrálható.

Az oktatási segédanyag következő eleme a használati útmutató, amelyben megtalálható a hallgatói kézikönyv, és a tanári útmutató. Modulonként tartalmazza a rendszer használatával kapcsolatos tudnivalókat. A dokumentumok segítenek a hallgatóknak és oktatóknak a modell használatának elsajátításában. Az oktatási segédanyag az ERP rendszer teljes körü dokumentációját tartalmazza, amelyben megtalálható a rendszer müködésének leírása képernyőképekkel, magyarázatokkal.

Az vállalatirányítási rendszerek oktatásában fontos szerepet kapnak azok a megoldások - elearning megoldások -, amelyek segítségével nem iskolai keretek közt - elsősorban otthon oldhatják meg a feladatokat a hallgatók. Az esettanulmányokban megfogalmazott gazdasági helyzeteket a hallgatók a tananyag és a képernyőképek segítségével interaktív módon tudják követni, a feladatokat meg tudják oldani. A modellben a rendszer használatának elsajátításához interaktív videók állnak a hallgatók rendelkezésére. A videókon három féle módon követhetik nyomon egy-egy feladat megoldásának lépéseit. Egyrészt folyamatosan, megszakítások nélküli, másrészt minden lépésnél megszakított videó segítségével. A harmadik lehetőség a tényleges interaktív feladatmegoldás, amikor a létrehozott videóban elhelyezett utasításoknak megfelelően kell a hallgatónak a megfelelő helyre kattintva, a megfelelő mezőbe adatot beírva eljutni a feladat megoldásához. Ezzel lehetővé válik a tanórán kívül történő feladatmegoldás, illetve a rendszer használatának gyakorlása.

\section{Az ERP rendszer oktatásának beépítése, képességek fejlesztése}

A rendszerek nagyon fontos jellemzője, hogy úgynevezett modulokból épülnek fel, aminek eredményeként akár a teljes vállalati struktúrát képesek lefedni. Ennek hatására megszünnek az úgynevezett szoftverszigetek, amelyek nagy hátránya, hogy a különböző szervezeti egységek által rögzített adatok más szervezeti egységek nyilvántartásaiban csak különböző „trükközések”, ismételt rögzítés által kerülhetnek be. A moduláris felépítésnek másik fontos előnye, hogy lehetővé válik a rendszerek modulonként történő bevezetése. Ezt a tulajdonságot 
használtuk ki, amikor elkezdtük a vállalatirányítási rendszerek gyakorlatorientált oktatását. A következő tényböl indultunk ki: mivel egy ilyen rendszer képes valamennyi - a vállalat müködéséhez kapcsolódó - folyamatot kezelni, a legkülönfélébb tantárgy keretében nyílik lehetőség egy-egy funkció bemutatására. Az előzetes tervek szerint ezek a következők voltak:

- Controlling

- e- Business

- Folyamatmenedzsment

- Logisztika

- Projektmenedzsment

- Stratégiai és üzleti tervezés

- Vállalatgazdaságtan

- Vállalati információs rendszerek

- Vállalati pénzügyek

- Vezetői számvitel

Az elmúlt években több ezer hallgató ismerkedett meg legalább egy szemeszteren keresztül az ERP rendszerek használatával. Közülük voltak, akik további szemesztereken át a fenti kurzusokon használták ki az ERP azon tulajdonságát, hogy a legkülönfélébb gazdasági folyamatokat modellezik, így a kurzus egy-egy témakörének feldolgozásakor segítségül tudták hívni.

Az elsődleges cél az oktatási tematika kialakításával, hogy ne csak az információ előállítását, összegyüjtését szemléltessük, hanem azt is, hogyan lesz az egyszerü papír alapú adathordozón rögzített adatból elektronikus adat, majd pedig jelentés. Az oktatásban alkalmazott programok jól szemléltetik a rendszerek következő tulajdonságait:

- Folyamatszemléletüség

- Moduláris felépítés

- Standardizálhatóság

Az ERP rendszerben való munkához egy általunk kialakít oktatási modell és az ERP használatát segítő esettanulmány csomag, videó anyag illetve vállalati adatbázis nyújt segítséget. Az alábbi felsorolás bemutatja, hogy milyen szituációkba kell a hallgatóknak beleképzelni magukat egy-egy feladat végrehajtása során:

\begin{tabular}{|l|l|l|}
\hline ABC analízis & Ajánlat - önköltség & Ajánlat - számla \\
\hline BGC mátrix & Beruházás & Beszállítói verseny \\
\hline Beszerzés - diszpozíció & Boltnyitás & Csomagoló anyag \\
\hline Egyedi igények & $\begin{array}{l}\text { Felkészülés autóipari } \\
\text { beszállításhoz }\end{array}$ & Hitelkérelem \\
\hline Időbeli elhatárolás & Ingatlan - beruházás & Javítási megbízás \\
\hline Kampánytervezés - reklám & Kapacitás - fedezetszámítás & $\begin{array}{l}\text { Készletgazdálkodás - minimum } \\
\text { készlet }\end{array}$ \\
\hline Költségszámítás & Költségszámítás - készlet & Likviditás - fizetési magatartás \\
\hline Pénzügyi diagnózis & Pénzügyi mutatók & Teljesítménybér \\
\hline Új technológia & Új termék projekt & \\
\hline
\end{tabular}

Az esettanulmányok végén különböző nehézségi fokú kérdésekre kell válaszolni a hallgatóknak. A feladatok megoldásához szükséges segédanyagokat leírás és videó anyag formájában otthonról is elérhető portálon találják meg.

A 4. ábra a portál látogatottságát mutatja. 

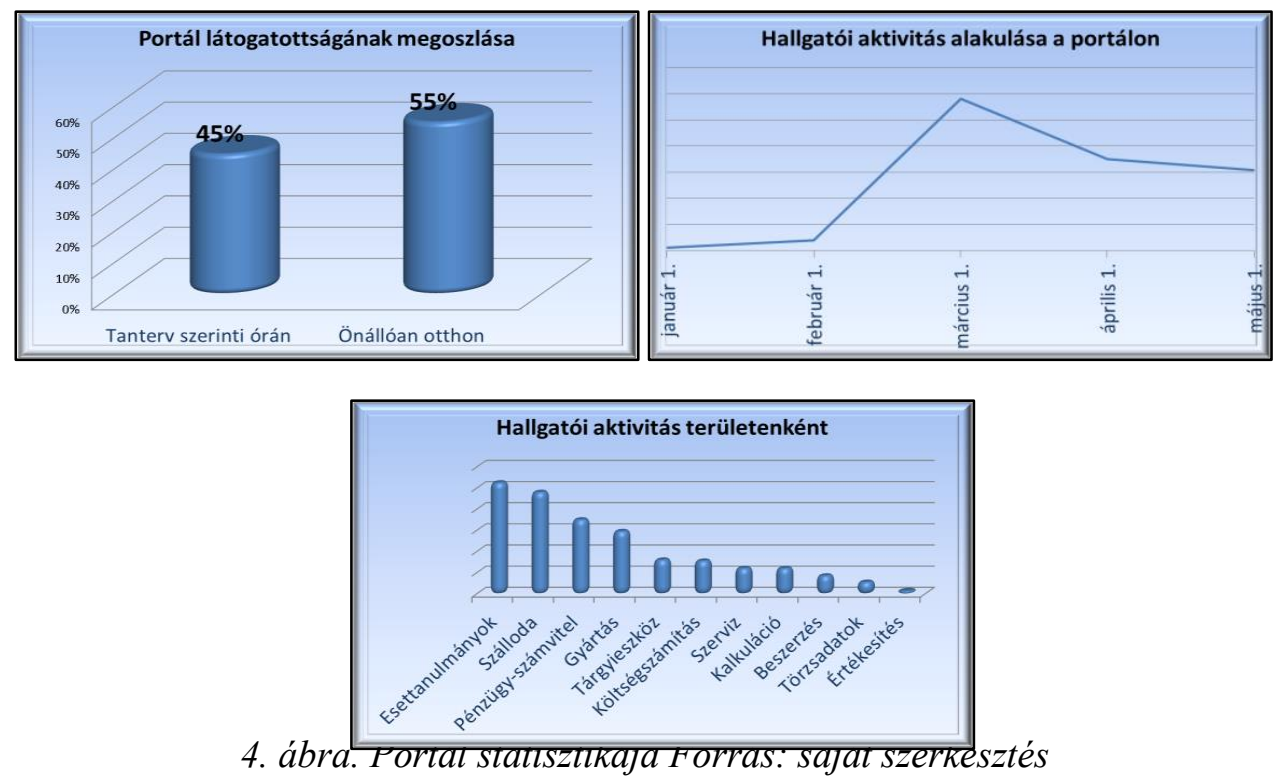

Időt szántak a feladatok megoldására, illetve a szorgalmi időszakban szinte folyamatos volt a portál használata. Az is jól látható, hogy elsősorban az esettanulmányokat tartalmazó oldalakat látogatták leggyakrabban, illetve, a vendéglátáshoz, pénzügyekhez, gyártáshoz kapcsolódó segédanyagokat vették igénybe.

\section{Oktatási tapasztalat, vélemények}

Az eltelt évek alatt folyamatos a kapcsolat az oktatott programokat szállító cégekkel, tapasztalatainkat kíváncsian fogadják. Elmondható, hogy sikerült megtalálni azokat a leglényegesebb területeket a rendszerek oktatásában, amelyek ismeretének birtokában szívesen fogadják végzett hallgatóinkat az állásinterjúkon. Igényként jelent meg a munkaadók részéről, hogy az általános ismereteken túl szívesen vennék, ha egy konkrét szakterületet, modult nagyobb részletességgel mutatnánk be. Itt elsősorban a logisztikai folyamatok és az ehhez kapcsolódó modul használatának elsajátítása valamint a informatika területén a programozási feladatok ellátása fogalmazódott meg.

A munkaadók mellett a hallgatók véleményére is kíváncsi voltam az ERP rendszerek oktatásának hasznosságával kapcsolatban. A véleményeket mutatja az 5. ábra. 


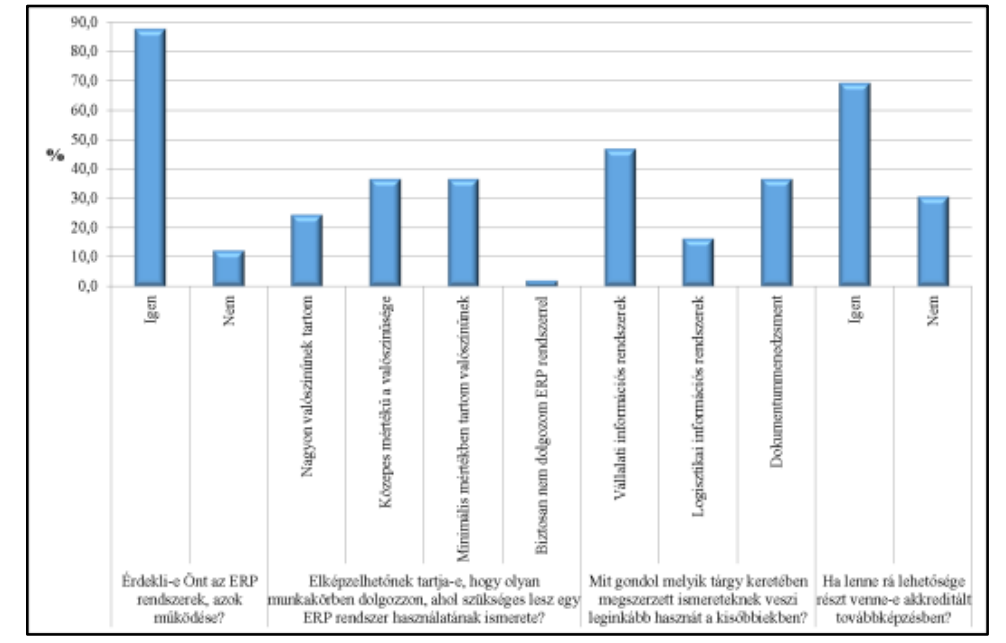

5. ábra. Hallgatói vélemények a vállalati információs rendszerekröl

Forrás: saját szerkesztés

Az ábráról leolvasható, hogy a hallgatók közel 90 \%-át érdekli az ERP müködése, és körülbelül $60 \%$-ban valószínüsítik legalább közepes mértékben, hogy a későbbiekben is szükségük lesz az elsajátított ismeretekre. A megkérdezettek majdnem $70 \%$-a további képzésben is szívesen részt venne. Az 1. és 2. táblázat a fenti kérdések további összefüggéseit mutatja.

1. táblázat. Az információs rendszerek iránt érdeklődők tanfolyamon való részvételi hajlandósága Forrás: saját számitás

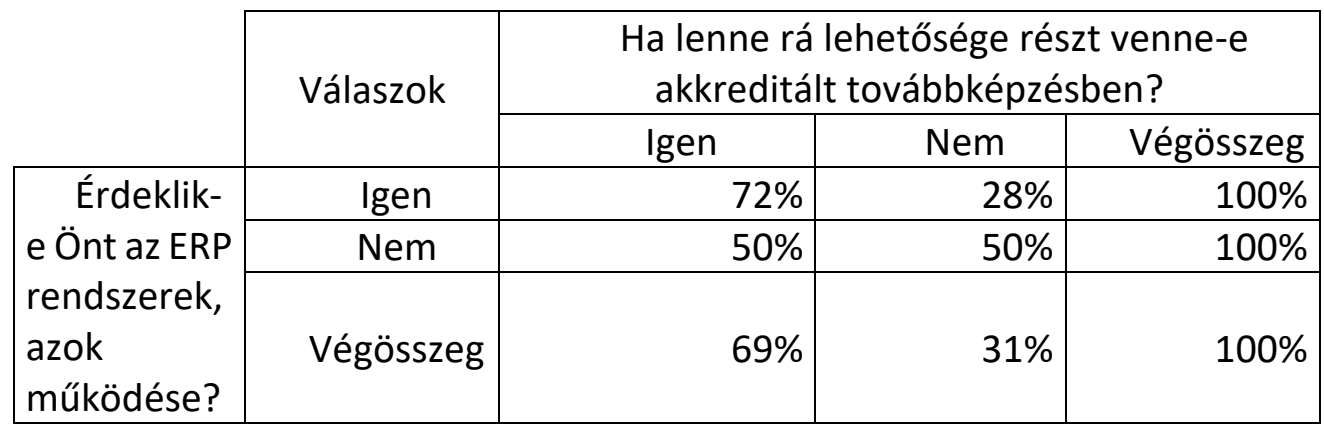

A felmérés alapján jól látható, hogy az érdeklődő hallgatók majdnem háromnegyede lenne hajlandó elmélyíteni ismereteit továbbképzés keretében. Az 1. táblázatból az is leolvasható, hogy a nem érdeklődő hallgatók fele szintén részt venne további tanfolyamon, ha erre lehetősége nyílna. Ennek okát mutatja a 2. táblázat. 
2. táblázat. Az információs rendszerek iránt érdeklődők véleménye a jövőre vonatkozóan Forrás: saját számitás

\begin{tabular}{|c|c|c|c|c|c|c|}
\hline & \multirow[b]{2}{*}{ Válaszok } & \multicolumn{5}{|c|}{$\begin{array}{l}\text { Elképzelhetőnek tartja-e, hogy olyan } \\
\text { munkakörben dolgozzon, ahol szükséges lesz egy } \\
\text { ERP rendszer használatának ismerete? }\end{array}$} \\
\hline & & $\begin{array}{l}\text { Nagyon } \\
\text { valószínú } \\
\text { nek } \\
\text { tartom }\end{array}$ & $\begin{array}{l}\text { Közepe } \\
\text { s } \\
\text { mérték } \\
\text { ű a } \\
\text { valószí } \\
\text { n- } \\
\text { ûsége }\end{array}$ & $\begin{array}{l}\text { Minimál } \\
\text { is a } \\
\text { valószín } \\
\text { űsége }\end{array}$ & \begin{tabular}{|c} 
Biztosan \\
nem \\
dolgozo \\
m \\
informá \\
ciós \\
rendszer \\
rel \\
\end{tabular} & $\begin{array}{c}\text { Végössz } \\
\text { eg }\end{array}$ \\
\hline \multirow{3}{*}{$\begin{array}{c}\text { Érdeklik-e } \\
\text { Önt az } \\
\text { ERP } \\
\text { rendszere } \\
\text { k, azok } \\
\text { múködése } \\
\text { ? }\end{array}$} & Igen & $28 \%$ & $42 \%$ & $30 \%$ & $0 \%$ & $100 \%$ \\
\hline & Nem & $0 \%$ & $0 \%$ & $83 \%$ & $17 \%$ & $100 \%$ \\
\hline & $\begin{array}{l}\text { Végöss } \\
\text { zeg }\end{array}$ & $24 \%$ & $37 \%$ & $37 \%$ & $2 \%$ & $100 \%$ \\
\hline
\end{tabular}

Megállapítható, hogy az ERP rendszerek iránt nem érdeklődők is - minimálisan ugyan, (83 $\%$ ) - valószínüsítik, hogy a jövőben szükségük lehet a megtanultakra. Ennek is köszönhető az akkreditált tanfolyamon részt venni kívánkozók magas aránya, hiszen további gyakorlatot szerezhetnek az integrált rendszerek kezelésével kapcsolatban.

Összefoglalásként a következő megállapításokra jutottam:

- A gyakorlatorientált oktatás előtérbe helyezése jó döntésnek bizonyult, mert a hallgatók maguk is érzik az ERP rendszerek fontosságát.

- A kialakított vállalati adatbázis struktúra elősegíti, hogy hallgató a feladatokat végre tudják hajtani.

- Az egyedi kódstruktúra használatával a hallgatók tevékenysége folyamatosan nyomon követhető az integrált rendszeren belül is.

- A létrehozott oktatási forma és tematika alkalmazható az alap és felsőoktatási szakképzésben, a felnőttképzésben egyaránt.

- Mindamellett, hogy a hallgatók elsajátítják az ERP rendszerek kezelésének lépéseit, fontos hangsúlyozni, hogy a vállalatoknál alkalmazott rendszerek jóllehet eltérnek a megismerttől, de az alapvetö folyamatok a gyakorlatban sem müködnek másként.

A továbbiakban van még lehetőség a fejlödésre, amit újabb kurzusok, és gazdasági területek ERP oktatásába való bevonásában látok. 


\section{Irodalomjegyzék}

Hágen, I. Zs.-Kondorosi, F. 2009. Üzleti tervezés. Debrecen: Controll Kft. pp. 17-110.

Lucey, T. 1989. Management Information System. London: DP Publications. 357 p.

Webmethods. 2000. Business Integration ROI, Building The Business Case For integration. URL: http://whitepapers.tabtimes.com/whitepaper657 (2012. 07.13)

Zörög, Z.-Ficzeréné, N. K.-Bakos-Tóth, E. 2010. A Sarbanes - Oxley törvény hatása a vállalatok belső ellenörzésének alakulására, valamint informatikai támogathatósága és azok pénzügyi vonatkozásai. „Hitel, világ, stadium” Nemzetközi konferencia, Sopron, 2010. November 3. pp. 72

EUROSTAT. 2015. URL:

http://appsso.eurostat.ec.europa.eu/nui/show.do?wai=true\&dataset=isoc_bde15dip 